\title{
平地屋敷林における微気象効果と管理による相違
}

\section{The Effects of Premises Forest by the Control of Microclimate}

\author{
岡田 穣* 浅川昭一郎* \\ Minoru OKADA Shoichiro ASAKAWA
}

\begin{abstract}
摘要：本研究では屋敷林の微気象改善機能を再確認し，管理による効果の違いを検証するために，平 地の単列屋敷林において枝打ち管理の施業前, 施行後の微気象を観測・比較した。その結果, 枝打ち 前の観測では冬期における防風・防雪効果, 夏期における防風・気温調節効果が確認されたが, 屋敷 内における冬期の堆雪, 夏期の気温におけるデメリット面もみられた。しかし枝打ち後の観測で屋敷 内における積雪の軽減, 夏期の気温の低下が認められた。以上により, 土地利用上多くの列を植栽す ることが難しい屋敷林が, 通年的・複合的に微気象改善機能を持ち, かつ十分有効であることが示さ れた。また，枝打ちを行うことにより微気象機能が更に向上することが示され，この面からも屋敷林 の管理が必要であることが認められた。
\end{abstract}

\section{1.はじめに}

屋敷林は防災機能を目的の一つとして人為的に形成され，それ らの多くは災害等の苦い経験之災害を防止するための工夫を積み 重ねてつくりあげられてきたもの年で, 防風をはじめ防雪・防火・ 日陰機能，薪炭材・用材供給等，様々な役割を持ち，平野部で生 活する人々にとって最屯生活に密着し，身近な林の1つである。 また，屋敷林は農村集落景観においても数少ない垂直的な景観構

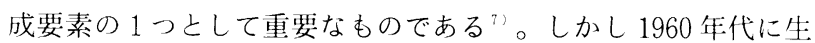
じたエネルギー革命により，平地における屋敷林の最も重要な機 能の一つであった薪炭材供給機能の必要性は殆ど消失した。また, 茅莫き屋根が瓦や鉄板の屋根に替わり, 建物自体む気密性が強化 される等, 住宅構造の変化に伴い, 防風機能や防雪機能む従来ほ どの必要性がなくなってきている。また, 安価な海外材の輸入や 材質の变化により, 建築材や農業資材としての資材供給機能も必 要性が消失しつつある。このように近年の生活様式の变化に伴い, 私有地内の屋敷林は管理が困難等の理由も重なり伐採され, 具体 的・効果的な保全措置が講じられないまま減少している3”。今後, 屋敷林を保存・造成していく場合, 農村景観に招ける景観構成要 素の一つとして, 景観面で保存・造成していく方向性が考えられ, 景観保全地区条例（岩手県胆沢町）や景観保全対策推進協議会 （島根県斐川町）などの活動例 ${ }^{4.5}$ もみられるが，実際に屋敷林の ある屋敷で生活する住民達からは総論的には賛成なものの, 管理 面の個人負担の大きさ等功否定的な各論的意見もきかれ, 景観 面のみを前に出した方向性ではその維持は困難であると思われ る ${ }^{11}$ 。そこで屋敷林の本来の成立要因である機能面に注目した場 合, 樹林の持つ物理的特性を利用して, 生活環境の改善を四るこ とが近年ますます重要視されており，計两的に樹林を配置してい くのに必要な裹付けとなる理論, 技術の解明が要請されている ${ }^{(4)}$ 。 実際住民も機能面に関する屋敷林への期待が大きく ${ }^{22}$, 人工物で は代替することのできない樹林の持つ通年的, かつ複合的な機能 に着目することが重要であると考えられる。しかし従来の機能の 必要性が薄れていることを考慮すると, 新たな機能的な存在意義 を確立することが必要であり,「気象災害から守る」という防災 機能ではなく, これからは「気象をコントロールする」という改 善機能に注目する必要があり, 屋敷林のもつ微気象改善機能を生 かすことが，新たな機能的な存在意義の確立の中心になると思わ れる。しかし樹林の持つ機能についての報告は多くが耕地防風林
といった多くの列によって構成された林带を対象としており, 土 地利用上, 単列林が主流である屋敷林の機能報告は少ない。また 現状の屋敷林の微気象に与える影響についての報告 ${ }^{7.16}$ はあるも のの, 屋敷林と同様に資材供給機能等を持つ里山林が, 放置され ることにより従来の機能を失っている ${ }^{2)}$ の同様に, 屋敷林屯放 圆により従来もつ機能が低下していると考えられ，屋敷林のもつ 機能の現状の把握之同時に, 管理による機能の向上を検証する必 要があると思われる。

本研究は単列林が主流である屋敷林の持つ通年的・複合的機能 のうち, 微気象改善機能を再確認し, 管理前之管理後之の効果の 違いを検証し, 今後の屋敷林の保全, 管理への具体的な提言をす る際の礎とすることを目的とする。なお今回は, 防風に最も効果 的な防風林構造の 1 つの指標が「樹木の下層が踈で上層が密な林 帯」 ${ }^{15)}$ とされている点に着目し，管理作業は簡単な枝打ちとして 検証を行った。

\section{2. 調査地概要}

\section{（1）周辺の概況}

調査対象地は北海道恵庭市林田地区（図一-1）である。当地は 北海道最大の平野である石狩平野（石狩低地帯）の南部で，札幌 の南東約 $30 \mathrm{~km}$ ，北海道の中心都市である札幌市之，空の玄関口 である千歳市のほぼ中間に位置し，地質は砂質壤土および泥炭地 である ${ }^{1)}$ 。対象地は北広島市，恵庭市，千歳市にまたがる恵庭土 地改良区内の北西部に位置し, 改良区の平地部を含む筆者ら の研究対象地域内に位置する。研究対象地域の西側には道央自動 車道, 国道 36 号線, JR 干歳線に沿って市街地拡張が進行してお り, 研究対象地域内も 1980 年に南西部に恵み野地区が造成され るなど, 市街化の進展の影響を受けている。研究対象地域内の土 地利用は水田之畑地がほぼ同面積で, 過去 40 年間の傾向之して は, 水田が減少，畑地が増加傾向にある ${ }^{10 !}$ 。研究対象地域内にお ける樹林之しては主に屋敷林, 防風林, 社寺林, 河畔林等がみら れ, 過去 30 年間の傾向としては樹林全体は増加しているものの, 屋敷林は減少傾向にある ${ }^{9}$ 。調査地付近では偏西風が西側の後志 火山性台地に阻まれて太平洋岸にまわり，東側の夕張山地にも阻 まれて卓越風が南から北へ吹き抜ける。その風は太平洋を通った 結果寒流の影響を受け, 南風にもかかわらず冷涼で海霧を伴い (日照不足を伴う), 農業にも生活にも好ましくない風になってし

\footnotetext{
*北海道大学大学院 農学研究科
} 
まう。そのため, 周辺にある恵庭営林署管轄の幹線防風林（防風 保安林）は, ほぼ南北の林帯, ほぼ東西方向の林带との 2 方向に 配置されている ${ }^{13)}$ 。

\section{（2）屋敷および屋敷林の概況}

本研究では枝打ち管理による機能効果の変化をみるため, 枝打 ちによって形態的な变化が明確な針葉樹の単列屋敷林を対象とし た。対象地の周辺（筆者ら ${ }^{9.10}$ における研究対象地域）の屋敷林 は現地調査より, 全屋敷（ $\mathrm{N}=694$ : 研究対象地域内で現在む居住 している屋敷の総数）の約 $70 \%$ が主に針葉樹で構成された屋敷 林であり，対象とした屋敷林はこの周辺でごく普通に見られる代 表的なむのとみなすことができる。対象地の周囲は畑地で囲まれ ており, 屋敷面積は約 $4,400 \mathrm{~m}^{2}$ と, 研究対象地域内の屋敷面積の 平均值 $3,500 \mathrm{~m}^{2}$ （最低 $600 \mathrm{~m}^{2}$, 最高 $40,100 \mathrm{~m}^{2}$ ）よりやや広い。屋 敷林は図-2 のとおり屋敷の四方に存在し, 主として二オイヒバ, アカエゾマッ，ヨーロッパアカマッ，イチイといった常緑針葉樹 で構成されている。屋敷林の各方位の樹高, 枝下高, $\mathrm{DBH}$ おょ び植栽間隔の平均值，主な構成樹種を表一 1 に示す。屋敷林は主 に約 25 年前に植栽されたもので，アカエゾマッ，ニオイヒバに よる年輪調查の結果と所有者への聞き取り調査の結果とはほぼ一 致していた。なお所有者は現在この屋敷で生活しておらず，1999 年まで居住していた住民も屋敷林管理は全く行っていない。対象 地内における屋敷林は現地調查より, 図一 3 のとおり, 約半数の 屋敷林が枝打ち管理を行っておらず，約 $80 \%$ の屋敷林で枝下高 が $50 \mathrm{~cm}$ 以下（葉が枯れ落ちたものも含む）であった。

\section{3. 調查方法}

(1) 微気象調査 (枝打ち前)

枝打ち管理前の微気像調查として, 1999 年 2 月〜 4 月 (冬期), 1999 年 7 月（夏期）の 2 期に, 図-4 のとおり, 屋敷林周囲で 風速, 積雪深, 気温の観測を行った。風速・気温調查には KANOMAX 社製多点アネモマスター多点観測計を用い, 地上 高 $1.5 \mathrm{~m}$ にプローブを設置し，観測した。

冬期において, 風速は南側屋敷林において, 単列林部, 2 列林 部の林周辺および林間部（図－40(4)〜 (10) で 1999 年 2 月 9 日

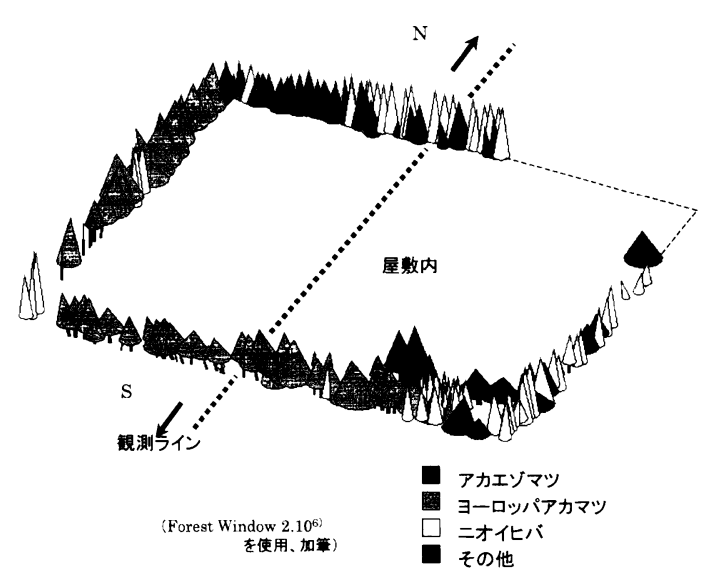

図一２調査地屋敷林鳥瞰図

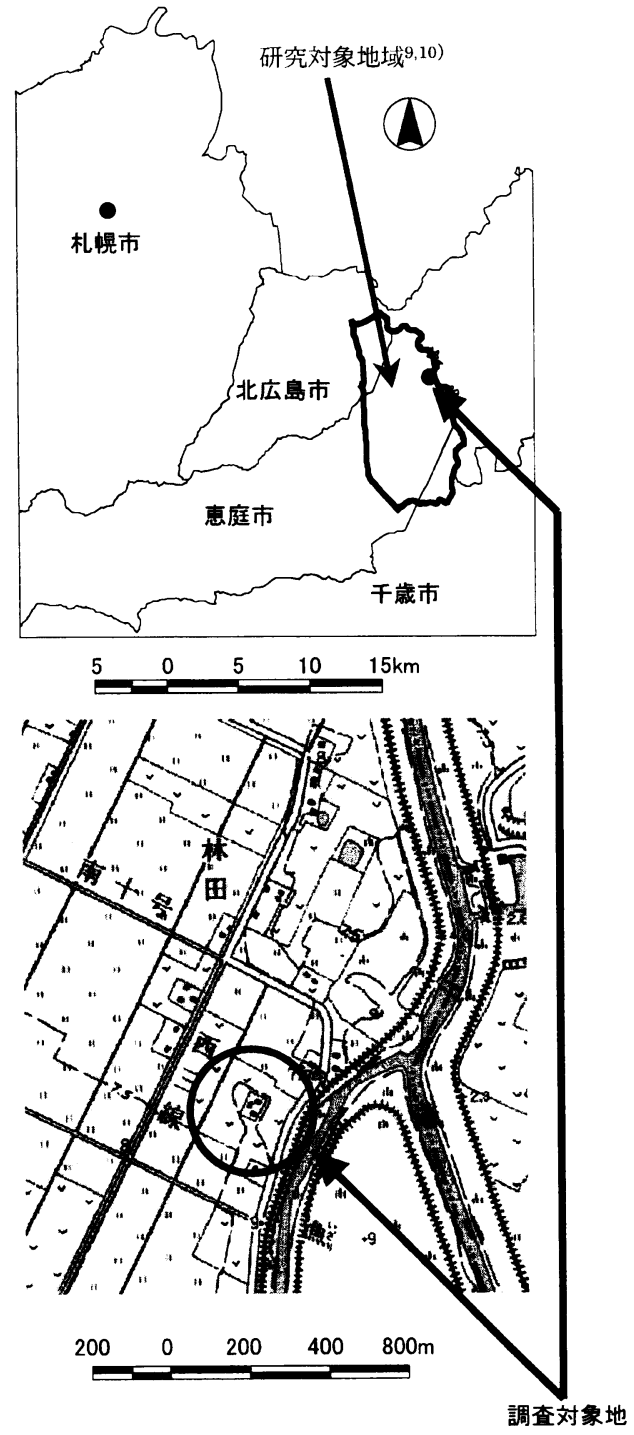

図-1 調查対象地

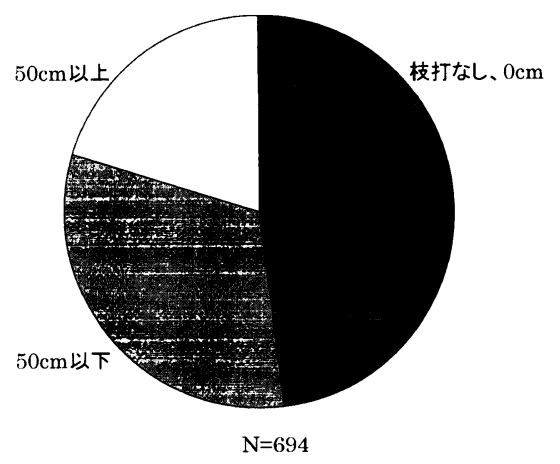

図ー 3 対象地周辺における屋敷林の下枝の状態

表-1 屋敷林の樹高, 枝下高, DBH, 主な構成樹種（枝打ち前）

\begin{tabular}{|c|c|c|c|c|c|}
\hline \multirow[b]{2}{*}{ 屋敷林位置 } & \multicolumn{3}{|c|}{ 平均値 $(\mathrm{cm})$} & \multirow[b]{2}{*}{ 植栽間隔 } & \multirow[b]{2}{*}{ 主な構成樹種 } \\
\hline & 樹高 & 枝下高 & $\mathrm{DBH}$ & & \\
\hline 東 & 380 & 40 & 6.1 & 111 & アカエゾマツ、ニオイビバ、イチイ \\
\hline 西 & 620 & 130 & 10.6 & 146 & ヨーロッパアカマツ \\
\hline 南 & 520 & 150 & 10.7 & 124 & ヨーロッパアカマツ、ニオイヒバ \\
\hline 北 & 560 & 30 & 8.1 & 75 & アカエゾマツ、ニオイ化バ \\
\hline
\end{tabular}


に 20 秒間隔で観測した。また, 同日に西側屋敷林, 北側屋敷林 において風下側の風速も測定した。なお，観測時の風向は現地で の観測より，常時 $\mathrm{S} \sim \mathrm{SE}$ 万向からであった。風下側の風速測定 では KANOMAX 社製クリモマスターを用い，地上高 $1.5 \mathrm{~m} に お ~$ いて $5 \mathrm{~m}$ 間隔で（林直後は $3 \mathrm{~m}$ 地点も） 1 地点につき 10 秒間に 10 回測定した平均值を移動観測した。積雪深は南側屋敷林（単 列部), 北側屋敷林の林内抢よびその周辺（図一 4の(1) (6)）で, 1999 年 2 月 4 日から林内・林周辺の雪が融雪した 4 月 14 日まで 週 1 回（積雪深の増加していた 2 月 10 日までは毎日），日中に観 測した。また，南北に1ラインを設定し，ライン上に設置した観 測点での観測む 3 月 10 日に行った。

夏期は冬期に設定したライン上にて，風速・気温の観測を 1999 年 7 月 21 日 13 時 10 分から 23 日 13 時 00 分まで 10 分毎, 48 時間観測した。

\section{(2) 枝打ち管理}

1999 年 10 月に 4 方向全ての屋敷林の枝打ち・ッル切りを行い
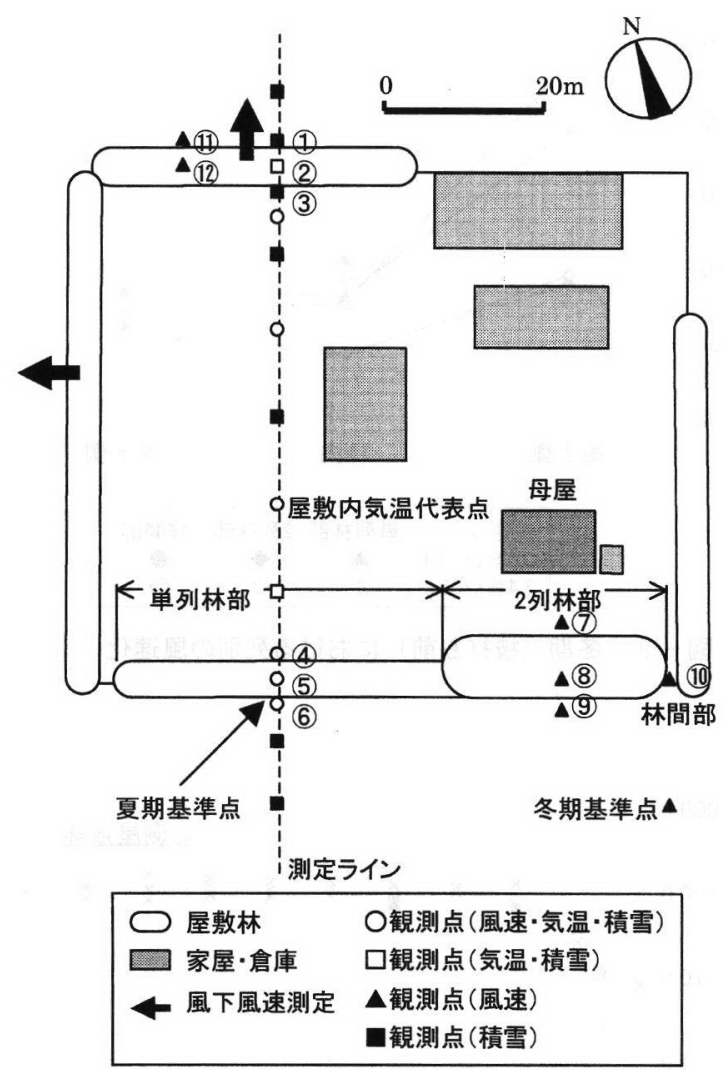

図－4 ライン設定・観測点位置模式図

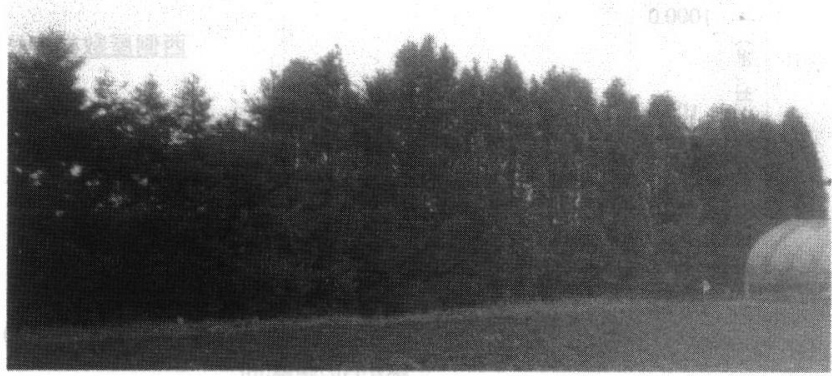

枝打ち前

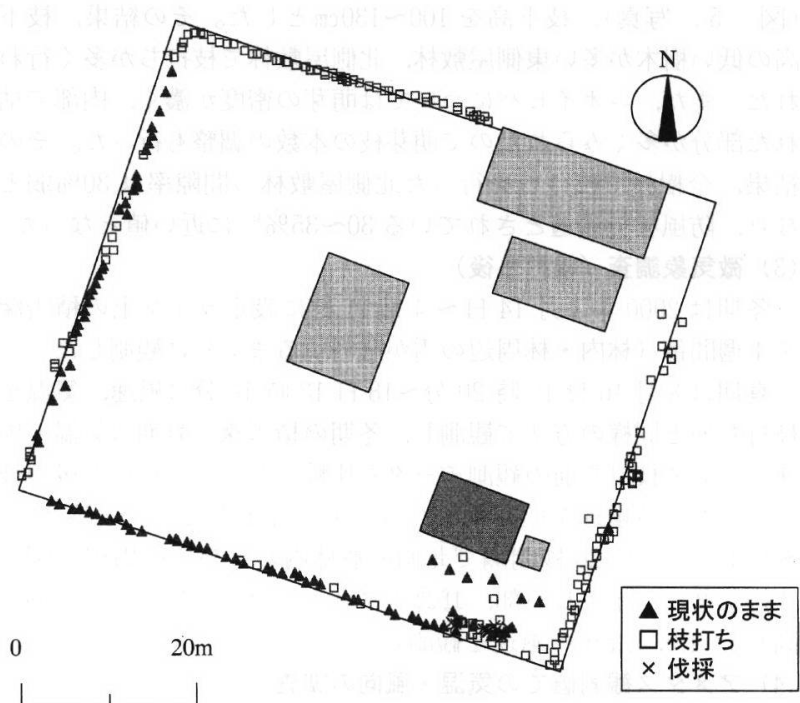

※全体でつる切りも行った

図ー 5 枝打ちの状況

\begin{tabular}{|c|c|c|c|c|}
\hline & \multicolumn{2}{|c|}{ アメダス } & \multicolumn{2}{|c|}{ 調查地 } \\
\hline & 1999年 & 2000年 & 1999年 & 2000年 \\
\hline 最高気温 & 29.9 & 30.2 & 32.1 & 31.9 \\
\hline 最低気温 & 17.2 & 14.0 & 15.7 & 14.2 \\
\hline 平均気温 & 23.3 & 22.6 & 22.5 & 22.7 \\
\hline
\end{tabular}

$1999 \cdot 7 / 21$ 13:10 7/23 13:00

$2000: 8 / 16$ 13:20 8/17 13:10

※アメダスはアメダス観測10分值データ

（気象庁 1999,2000）「恵庭島松」より作成

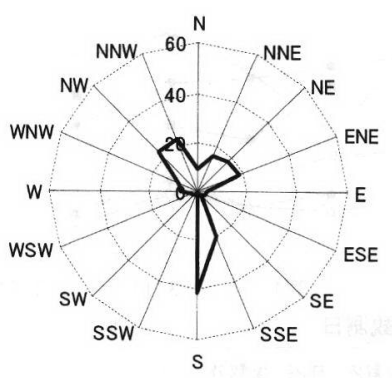

1999年 7/21 13:10 7/23 13:00

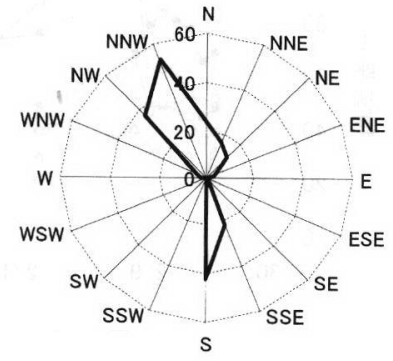

2000年

$8 / 16$ 13:20 8/17 13:10
図 -6 観測時の風向（度数）

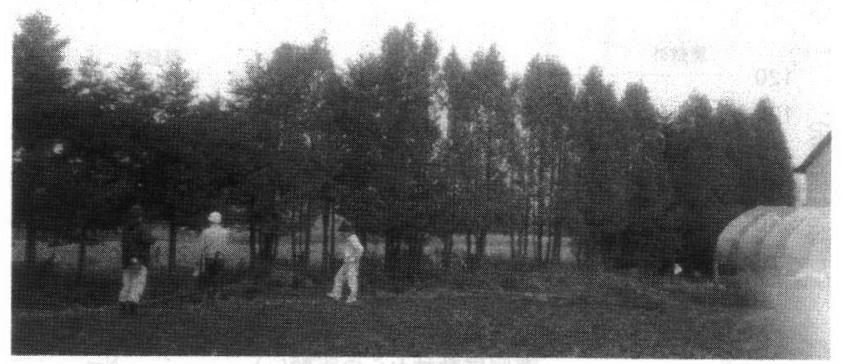

枝打ち後

写真 -1 北側屋敷林における枝打ち管理 
(図－5，写真)，枝下高を $100 〜 130 \mathrm{~cm}$ とした。その結果，枝下 高の低い樹木が多い東側屋敷林, 北側屋敷林で枝打ちが多く行わ れた。また, 二オイヒバについては萌芽の密度が濃く, 内部で枯 れた部分が多くみられたので萌芽枝の本数の調整も行った。その 結果，全樹林で枝打ちを行った北側屋敷林の間隙率は $30 \%$ 弱之 なり，防風林で最適とされている $30 \sim 35 \%{ }^{15)}$ に近い值となった。

(3) 微気象調査 (枝打ち後)

冬期は 2000 年 1 月 14 日〜 4 月 11 日に設定ライン上の積雪深 を 1 週間毎（林内・林周辺の雪が融雪するまで）に観測した。

夏期は 8 月 16 日 13 時 20 分〜 18 日 13 時 10 分に風速, 気温を 枝打ち前と同様の方法で観測し，冬期の積雪深，夏期の気温 ・風 速について枝打ち前の観測データと比較した。また枝打ち後の枝 下部における風速を把握するため, 2000 年 6 月 22 日 15 時 20 分 〜 15 時 50 分に 20 秒間隔で北側屋敷林内およびその周辺（図一 4 の(1)(2): 二オイヒバ部, (11)(12): アカエゾマッ部) において地上 高 $0.5,1.0,1.5 \mathrm{~m}$ の風速を観測した。

\section{（4）アメダス観測値での気温・風向の調査}

枝打ち前と枝打ち後との気象条件が同じであることの確認と, 分析時の条件をあわせるため, 調査地に最む近いアメダス観測点 （恵庭島松）における枝打ち前, 枝打後の夏期における気象観 測時の気温・風向の 10 分值デー夕を入手し, 調査地での気温・ 風向の基準とした。アメダス観測点㧍よび調査地の夏期基準点に おける気温を表－ 2 に，および風向を図－6に示す。その結果, 気温について，アメダス観測点では最高気温，平均気温が枝打ち 前（1999 年）と枝打ち後（2000 年）とでほぼ近い值で, 調査地 でむ最高気温・平均気温がほぼ同じだった。また風向は両時期 （枝打ち前, 枝打ち後）ともに主に南方向と北方向からの風が吹 いていた。今回の分析では南方向からの風の度数がほぼ同じだっ たこと, 強い風の殆どが S, SSE 方向からの風であったこと, 農

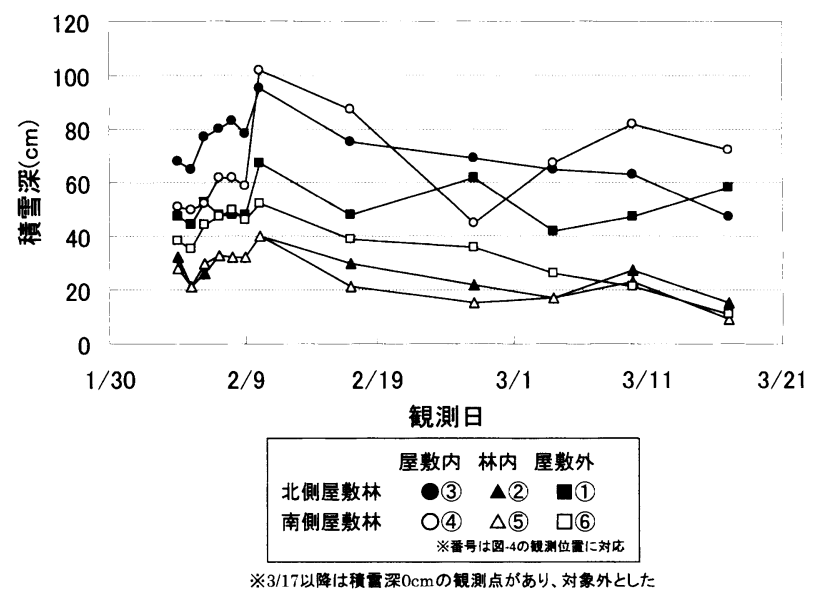

図－７屋敷林周辺の積雪深（1999.2.4～4.14）

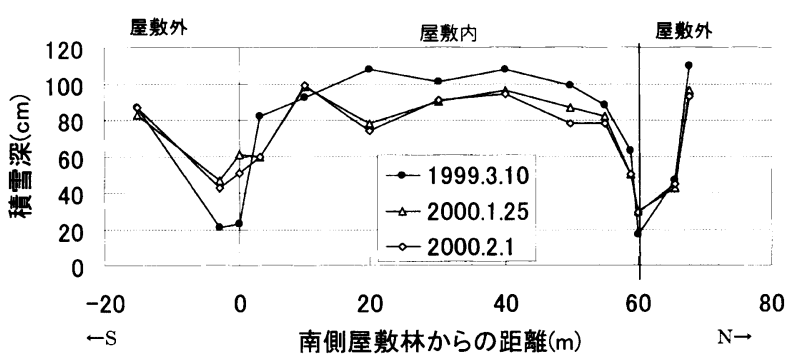

図ー8 ライン上の積雪深
業や生活に悪い影響を及ぼす風が南方向からの風である ${ }^{13)}$ ことか ら, 南方向からの風を対象亡し, 風速測定の分析においてアメダ スの 10 分值データで風向が S, SSE 方向の時刻のデータのみを 用いて分析した。

\section{4. 結果}

(1) 微気象調査（枝打ち前）

冬期の微気象結果は以下のとおりであった。積雪については図一 7 のとおり，林内で少なく，北側屋敷林の林内でも南側屋敷林の 林内でもほぼ同様の值がみられ，増減は小さかった。また，全般 に屋敷外よりも屋敷内のほうが少なかった。積雪深の低下傾向 （2/10 以降）については，屋敷内外に関係なく屋敷林南側（北側 屋敷林の屋敷内, 南側屋敷林の屋敷外）で順当に低下したのに対 し，北側は変動的であった。またライン上の積雪深は図一 8 のと おり, 大きな吹き溜まりは無いものの, 屋敷林から離れた屋敷中 央部を中心に屋敷内の積雪が屋敷外よりも多かった。風速につい ては, 多点観測計の観測において, 林周辺（林の前後 $3 \mathrm{~m}$, 図一

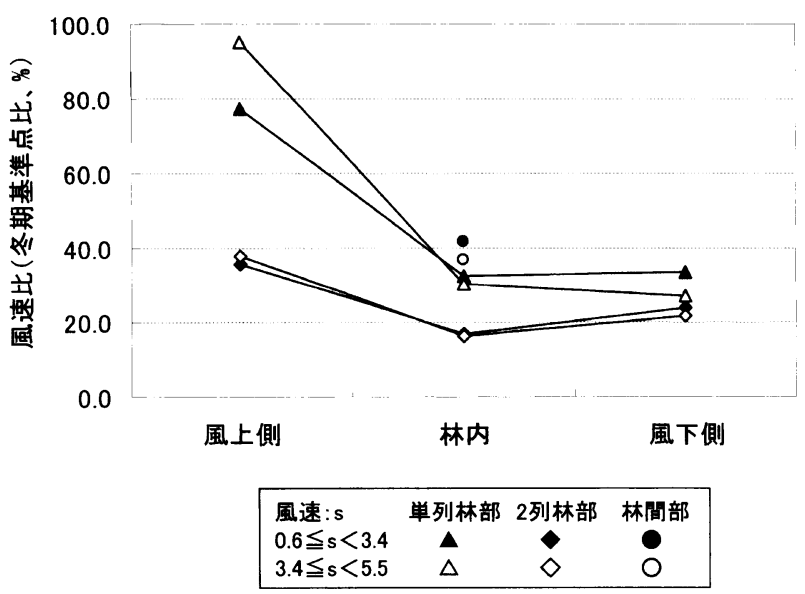

図一 9 冬期（枝打ち前）における列別の風速化
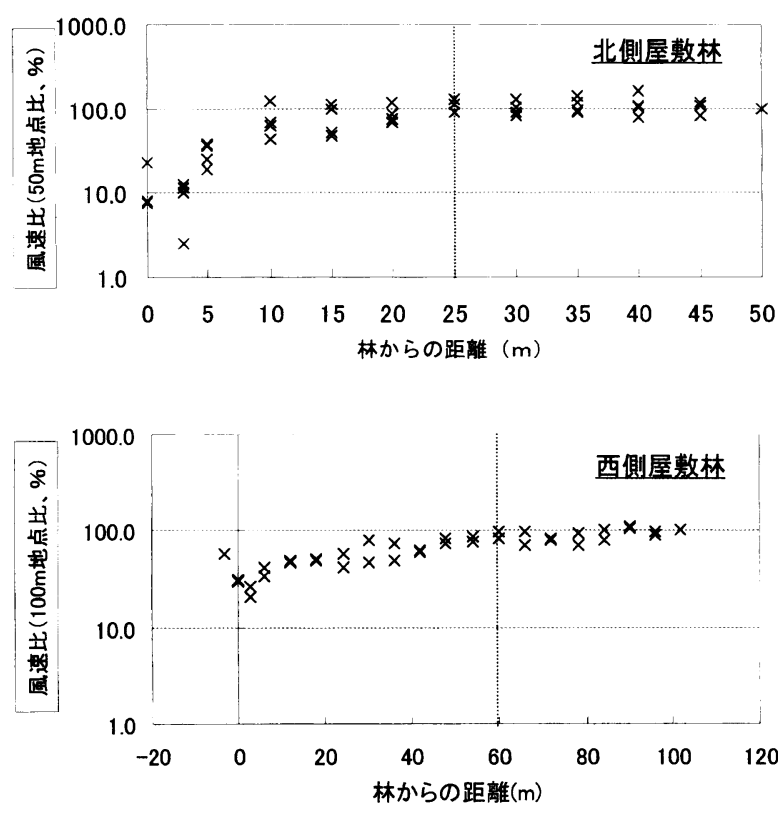

図-10 屋敷林風下側の風速分布（屋敷外） 
4 参照) では図 -9 のとおり, 基準点（図-4に示す冬期観測基 準点）に比べ風速は減少しており, その減少は林内, 風下側で著 しい。単列林部と 2 列林部, 林間部で比較すると, 全般に 2 列林 部の風速比が低く, 樹林の無い林間部で比較的高かった。しかし 単列林部と 2 列林部とで比較した場合, 林内, 風下側では風速比 の差が小さく, 特に風下側ではほぼ同様の風速比だった。また, 気象庁風力階級表に従い, 風速 $0.6 \mathrm{~m} / \mathrm{s}$ 以上 $3.4 \mathrm{~m} / \mathrm{s}$ 末満（風 速階級 2 ), 風速 $3.4 \mathrm{~m} / \mathrm{s}$ 以上 $5.5 \mathrm{~m} / \mathrm{s}$ 末満（風速階級 3 ）に分 けて観測デー夕をみた場合, 単列林部, 2 列林部とも, 風速階級 の違いによる風速比の差は大きくなかった。また北側屋敷林・西 側屋敷林の風下側風速測定では北側屋敷林は風下 $50 \mathrm{~m}$, 西側屋 敷林は風下 $100 \mathrm{~m}$ を基準とした場合, 図一 10 のと抢り, 林内では 北側で約 10\%, 西側で約 30\%まで減速していた。そして風下側 への減風効果の影響は, 北側屋敷林で約 $25 \mathrm{~m}$ (樹高の約 5 倍), 西側屋敷林で約 $60 \mathrm{~m}$ （樹高の約 10 倍）まで及んだ。

夏期の微気象の観測結果は以下のとおりであった。風速につい ては，屋敷外の基準点（図-4 に示す夏期観測基準点）と比較し た場合, 図一 11 のように, 南側屋敷林内の観測点（０ m地点） から風下側（屋敷内）は風速比が約半分以下になり, 北側屋敷林 （62m地点）の手前で更に風速比が低くなった。また, 気象庁風 力階級表に基づいた分類をすると, 風速が 0.6 以上 $3.4 \mathrm{~m} / \mathrm{s}$ 末満 (風速階級 2 ) よりも風速 $3.4 \mathrm{~m} / \mathrm{s}$ 以上 $5.5 \mathrm{~m} / \mathrm{s}$ 未満（風速階級 3）の風で屋敷内における風速比が低く, 風速が大きいほうが屋 敷林内, 屋敷内の風速比が低かった。気温については, 図一 4 に 示す夏期基準点を基準点として北側屋敷林内（図-4 に示す(2)， 南側屋敷林内（図-4 に示す(5), 屋敷内（図一 4 に示す屋敷内 気温代表点: 南側屋敷林から $20 \mathrm{~m}$ 地点）について, 気温差の経 時変化（図-12）をみると, 屋敷内では全般に基準点よりも気温 が高く, 屋敷林内では昼間（基準点の気温が高いとき）には基準
点より低くなり，主に夜間（基準点の気温が低いとき）は逆に基 準点より高くなる傾向が認められた。

\section{(2) 微気象調査（枝打ち後）}

冬期の微気象結果は以下のとおりであった。積雪については, 枝打ち前（1999 年）における屋敷外の積雪深とほぼ同值である 枝打ち後 $(2000$ 年) の積雪深との比較をした場合, 図一 8 のと おり，林内の積雪は増加したが，全般として枝打ち前に比べて減 少し, 屋敷内で比較的雪の多い部分が南側に移動した。

夏期の微気象結果は以下のとおりであった。風速については, 屋敷外を観測基準点として気象庁風力階級表に基づいて分類し， 枝打ち前の風速と比較した場合, 図一 11 のと抢り, 風速 $0.6 \mathrm{~m} /$ $\mathrm{s}$ 以上 $3.4 \mathrm{~m} / \mathrm{s}$ 末満（風速階級 2 ）の場合，枝打ち後は枝打ち 前と比べ，北側屋敷林の地点（62m地点）での風速比が高くなっ た。しかし全般に風速比は低く, $3.4 \mathrm{~m} / \mathrm{s}$ 以上 $5.5 \mathrm{~m} / \mathrm{s}$ 未満（風 速階級 3 ）の風は $40 \mathrm{~m}$ 地点までは枝打ち前よりも風速比が低く なった。また，枝打ち後も枝打ち前と同様，風速が大きいほうの 風速比が低くなった。また林内での地上高別の風速をみた場合, 表一 3 のと扔り，アカエゾマッの枝打ちされた部分（地上高 0.5 $\mathrm{m}, 1.0 \mathrm{~m}$ ) の風速は $4 \sim 6$ 割减少し, 萌芽成長している二オイ ヒバでは 6 割以上の減少（枝打ちしていない場合は 7 割）が認め られた。気温については，南側屋敷林南側（屋敷外。図一 4 に示 す夏期基準点）を基準点として屋敷内（図-4 亿示す屋敷内代表 点）での気温との相関図をつくり1次回帰式を算出し枝打ち前の 気温と比較した。その結果, 図一13のと拈り, 枝打ち前に気温 が屋敷外よりも全般に高かった屋敷内では，枝打ち前と枝打ち後 では 1 次回帰線の傾きは殆ど変化が無いものの切片值が低下して おり, 屋敷外気温が $15 \sim 30^{\circ} \mathrm{C}$ の範囲では, 屋敷内気温が枝打ち 後は枝打ち前よりも平均で約 $2{ }^{\circ} \mathrm{C}$ 低下した。

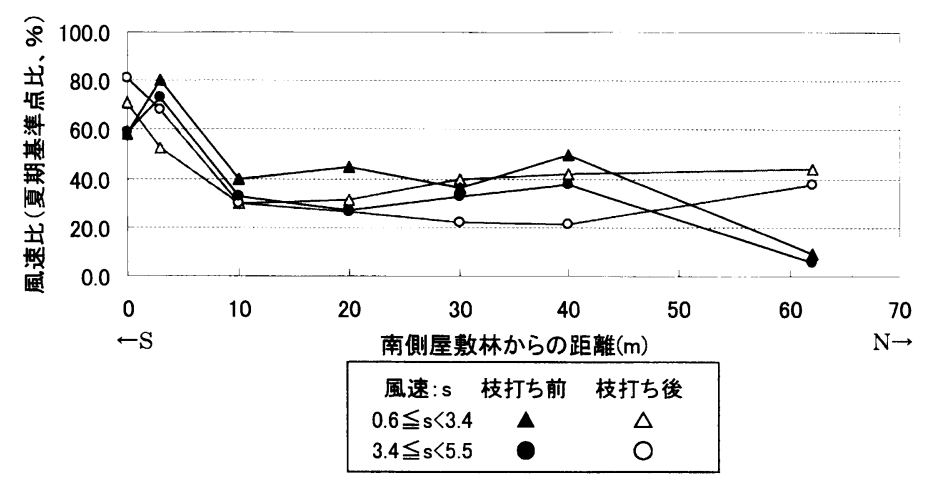

図-11 ライン上の風速化（南側から）

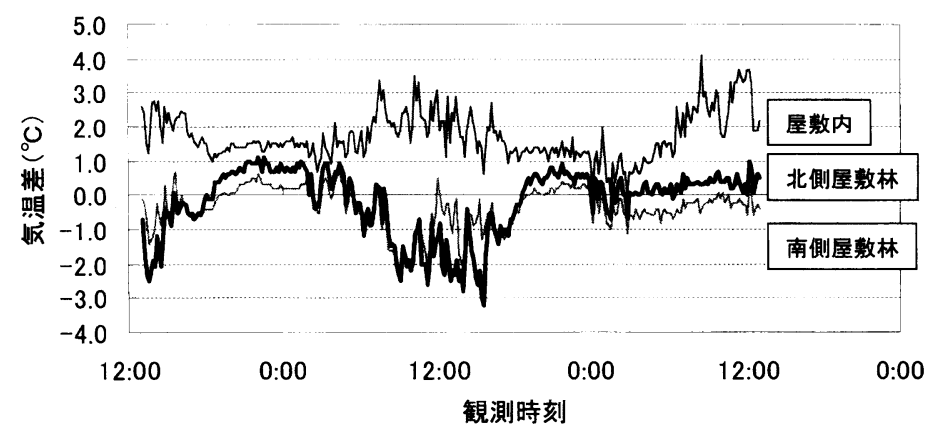

図－12 夏期基準点との気温差（1999.7.21 $13: 10 \sim 7.23$ 13:00）

\section{表一 3 北側屋敷林における地上高別風速化}

\begin{tabular}{ccc}
\hline \multirow{2}{*}{ 地上高 $(\mathrm{m})$} & \multicolumn{2}{c}{ 風速比(屋敷外比: \%) } \\
\cline { 2 - 3 } & アカエゾマッ & ニオイビ \\
\hline 1.5 & 14.6 & 35.6 \\
1.0 & 39.4 & 36.9 \\
0.5 & 54.3 & 34.7 \\
\hline
\end{tabular}

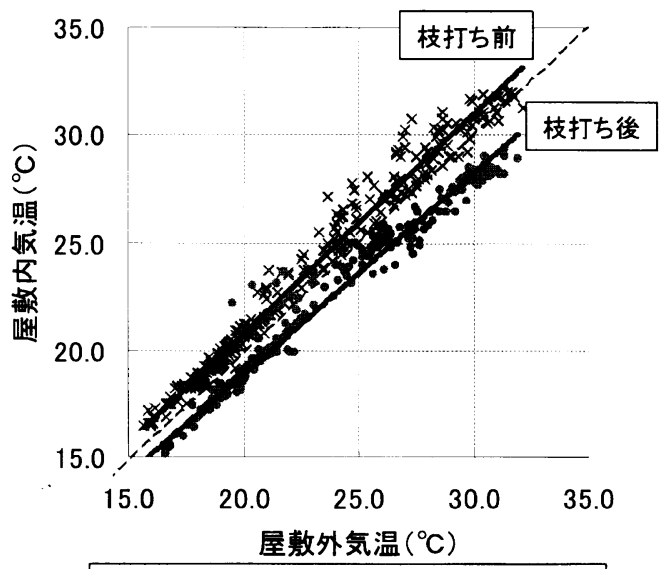

枝打前 $(x) \quad y=1.0228 x+0.3312 \quad R^{2}=0.9775$ 枝打ち後 (O) $y=0.9375 x+0.1305 \quad R^{2}=0.9749$

図-13 屋敷内の気温と屋敷外の観測基準点での気温 との相関図および 1 次回帰式 


\section{5. 考察}

\section{（1）屋敷林（単列林）の微気象改善効果}

以上の結果より，枝打ち前の観測では冬期における防風・防雪 効果が，夏期における防風・気温調節効果が確認された。防風効 果では単列林であっても十分な効果を発揮し，枝打ちによって枝 下高が高くなると防風効果が及ぶ範囲が長くなることも確認され た。また，防風の程度は，屋敷内では風速の強い場合のほうが弱 い場合より効果が大きいことがわかった。防雪効果では北側屋敷 林の林内でも南側屋敷林の林内でもほぼ同様の効果がみられた。 気温調節効果では，林内において，外部の気温が高いときには外 部より気温を低くし，外部の気温が低いときには外部より気温を 高くする効果がみられた。このように土地利用上多くの列を植栽 することが難しい屋敷林が，通年的・複合的に微気象改善機能を 持ち，かつ十分有効であることが示された。しかし問題点もみら れ，冬期には屋敷内に大きな吹き溜まりは無いものの屋敷内の積 雪が屋敷外よりも多いこと, 夏期において屋敷林の気温が屋敷外 よりも全般に高いといったデメリット面も確認された。

\section{（2）枝打ち管理による微気象改善効果の变化}

枝打ち後の微気象調査より, 風速については屋敷林の地点で風 速比が若干増加したものの, 屋敷内の風速は全般に屋敷外の半分 程度かそれ以下で, 枝打ち後のほうが防風効果の大きい傾向がみ られた。また，枝打ち前に確認されたデメリット面（屋敷内にお ける冬期の積雪の増加, 夏期の気温の上昇）をみると, 積雪では 屋敷内の積雪量が減少し防雪機能の向上が認められ, 気温につい ては，枝打ち前には屋敷外よりも高温であった屋敷内において気 温の低下が認められた。これは風速において強風時の風速比は変 化が小さく, 弱風時は風速比が高くなったことから, 適度な弱い 風が屋敷内に流入するようになったことによるあのと考えられる。 このように，屋敷林において枝打ちを行うことにより微気象が改
善されたことから，この面からも屋敷林の管理が必要であること が確認された。

\section{(3) 今後の課題}

今回の結果より，微気象改善機能を効率よく得るためには屋敷 林の管理が必要であることが示された。ただし, 今後の屋敷林の 保全・管理への提言を行う場合，具体的な指標が必要である。今 回の結果でも樹林の枝打ちによって枝下高が高くなると防風効果 が及ぶ範囲が長くなることも確認されたことから，より効果的な 微気象改善機能が得られる適切な枝下率, さらには樹冠部の透過 率をあわせた樹林の透過率（または遮蔽率）を指標とすることが 考えられる。また, 景観的にみた場合でも, 平地系農村景観の評 価の研究において樹林の適度な遮蔽率の存在が推測されており ${ }^{8\rangle}$, 今後の屋敷林の保存・管理を考えていく上で，機能的にも景観的 にも最適な樹林の透過率（遮蔽率）を解明し，具体的な管理指標 として提示する必要がある。そして最終的には屋敷林を平地系農 村において景観的にも機能的にも重要な「緑」として位置付け， 緑の骨格として考え ${ }^{3)}$, 適切な保全・管理を進めていくための助 言・提言をしていく必要がある。

\section{謝辞}

本研究を推進するにあたり, 快く調查に敷地を御提供頂き, 屋 敷林での微気象実験・枝打ち実験をさせて頂いた屋敷林の所有者 であるY氏, 調查地選定の際に地元の方との橋渡し等, 御足労 頂いた佐藤進氏, 実験に際しての実験手法や論文作成等について ご教示頂いた専修大学北海道短期大学の斎藤新一郎教授, 山形大 学大学院農学研究科の中島勇喜教授, また, 本論文の校閲に際し, 多くの的確なご意見・ご助言をして頂いた校閲者には深く感謝し, 記して謝意を表する。

\section{引用文献}

1）恵庭土地改良区（2000：共同水利開始 110 年 設立 50 周年記念誌 土緑水：恵庭土地改 良区, $196 \mathrm{pp}$

2) 石井実・植田邦彦・重松敏則（1993）：里山 の自然を守る : 築地書館, $171 \mathrm{pp}$

3 ) 勝野武彦・葉山嘉一 (1987)：都市近郊農業 地域の屋敷林構造とその保全に関する研究： 造園雑誌 50 (5), $191-196$

4) 北日本新聞社編（1982）：砥波散居村 緑の 知恵 : 北日本新聞社出版部, $142 \mathrm{pp}$

5 ) 村川三郎・西名大作・安野淳（1998）：住民 による地域の伝統的みよ゙り景観の評価構造 に関する研究：日本建築学会計画系論文集 $509,77-84$

6) Nobori,Y. (2000): Forest Window Methodology, Manual and Applications: Japan Society of Forest Planning Press, 100pp
7 ）野上一志・高橋新平・近藤三雄 (1996)：屋 敷林の防暑，防寒機能に関する実証的研究： 日本造園学会関東支部大会研究 - 報告発表 要旨 14,21

8 ) 岡田穣・浅川昭一郎（2001）：平地系農村景 観評価における樹林の意義と地域性：ラン ドスケープ研究 64(5)，741-746

9 ) 岡田穣・浅川昭一郎（2000）：北海道の水田 農業地域に㧈ける樹林帯の現状之変遷：日 本造溒学会北海道支部研究・事例報告発表 要旨 $4,26-27$

10）岡田穣・浅川昭一郎（1999）：北海道におけ る水田農業地域を事例とした土地利用と景 観の变化について：日本造園学会北海道支 部研究・事例報告発表要旨 $3,61-62$

11）岡田穣 - 中島勇喜 - 柳原敦 - 藤原滉一郎 (1998)：庄内平野の屋敷林に関する研究 （IV）住民の屋敷林に対する各論的対応一：
日林論 $109,215-218$

12）岡田穣 - 中江真理 ・ 中島勇喜 ・柳原敦・藤 原滉一郎（1997）：灰内平野の屋敷林に関す る研究（II）屋敷林の現状之問題点：日林 論 108, 209-212

13）斎藤新一郎（1996）：防風林の現況，風速の 測定, 抢上び防風林伐開後の影響評価と代 替施設について：恵庭市戸磯におけるユカ ンボン川の小規模改修工事に伴う防風保安 林解除の影響調查報告書, $108 \mathrm{pp}$

14）斉藤庸平・岩河信文・根岸茂（1990）：屋敷 林の防災機能に関する実証的研究: 造園雑 誌 53(5), 157-162

15）内嶋善兵衛編（1982）：現代の気象テクノ口 ジー4 農林・水産と気象 : 朝倉書店, $207 \mathrm{pp}$

16）山田恵子・田中一美（1988）: 屋敷林が微気 象に与える影響について: 都市公園 103, 71 $-73$

Summary: The purpose of this study was to reconfirm and compare the year-round microclimate control of a premises forest before and after cutting branches near ground. Results revealed that the premises forest provides effective protection from wind throughout the year, regulation of temperatures in summer and prevention from snowdrifts in winter. On the other hand, demerits, such as increase in snow and temperature inside the premises, were detected, but this was managed by cutting branches. As a whole, the results showed an enough improvement in the year-round microclimate of the premises forest even if the forest is formed by one row of trees due to the restriction of land use. As the microclimate improvement functions by the premises forest was intensified after cutting branches near ground, it could be concluded that managing premises forests is necessary also for the improvement of year-round microclimate of the site. 